\title{
Mapping QTLs for phenotypic and morpho-physiological traits related to grain yield under late sown conditions conditions in wheat (Triticum aestivum L.)
}

\author{
${ }^{1}$ Yaswant Kumar Pankaj, ${ }^{2}$ Lalit Pal, ${ }^{3}$ Ragupathi Nagarajan, ${ }^{4}$ Kulvinder Singh Gill, ${ }^{5}$ Vishnu Kumar, ${ }^{6}$ Sonali \\ Sangwan, ${ }^{7}$ Sourav Panigrahi, and ${ }^{8}$ Rajeev Kumar* \\ ${ }^{1}$ Division of Plant Pathology, Indian Agricultural Research Institute, New Delhi, India \\ ${ }^{5,7,8}$ Department of Agricultural Biotechnology and Molecular Biology, Rajendra Prasad Central Agricultural \\ University, Pusa, Bihar, India \\ ${ }^{2}$ Department of Plant Breeding and Genetics, Punjab Agricultural University, Ludhiana, India \\ ${ }^{4}$ Department of Crop and Soil Science, Washington State University, Pullman, USA \\ ${ }^{3}$ Department of Plant and Soil Science, Oklahoma State University Stillwater, Stillwater, Oklahoma, USA \\ ${ }^{6}$ Departmentof Molecular Biology, Biotechnology \& Bioinformatics, Chaudhary Charan Singh Agricultural \\ University, Haryana, India
}

\begin{abstract}
The elevating temperature makes heat stress one of the major issues for wheat production globally. To elucidate genetic basis and map heat tolerance traits, a set of 166 doubled haploid lines (DHLs) derived from the cross between PBW3438/IC252874 was used. The population was evaluated under Normal sown (NS) and late sown (LS) conditions, by exposing to heat stress during rabi season. The canopy temperature (CT) showed positive correlations with grain yield, whereas Soil plant analysis development (SPAD) was not significantly correlated and associated with GY in both the normal and late sown conditions. Composite interval mapping (CIM) identified total 12 Quantitative trait loci (QTLs) viz., 2 (Normal sown), 10 (late sown) mapped on linkage groups 1A, 1D, 2B, 2D, 3B, 4D, 5B and 6D, during both the crop seasons 2017-18 and 2018-19. Combining the results of these QTLs revealed a major stable QTL for grain yield (GY) on chromosome 3B with $11.84 \%$ to $21.24 \%$ explaining phenotypic variance under both sowing conditions. QTL for CT and SPAD was detected on chromosome 1A while QTL for GY on chromosome 3B and 5B. The identified QTLs in the genomic regions could be targeted for genetic improvement and marker assisted selection for heat tolerance in wheat. The tools like SPAD and CT could be exploited to screen the large number of breeding lines.
\end{abstract}

Key Words: Doubled haploid, Canopy temperature, Soil plant analysis development, Grain yield \& Quantitative trait loci

Abbreviation: SPAD: Soil plant analysis development; CT: canopy temperature; QTL: Quantitative trait loci; NS : Normal sown; LS : late sown; DH : Doubled haploid, GY: Grain yield; DHE: Days to heading; DMA: Days to maturity; PH: Plant height; BMAS: Biomass; TGW: Thousand grain weight; CIM : Composite interval mapping

\section{Introduction}

Wheat (Triticum aestivum L.) is one of the most widely grown food grain crops in the world. It contributes $20 \%$ dietary calories in the human diet (http://faostat.fao.org). Global warming has a significant effect on its yield reduction. The wheat is prone to heat stress which affects its production at a large scale. The elevated temperature has always a major impact on wheat production. The combined effect of heatwaves with drought is detrimental during the anthesis and grain-filling duration, which are the most vulnerable stage affecting the final yield (Ortiz et al. 2008). When the temperature exceeds the optimum value, the rate of photosynthesis in wheat decreases (Sage and Kubien, 2007) due to a reduction in the efficacy of photosystem II (Nash et al., 1985). According to Hertel et al., 2010 the global wheat productivity has lowered down up to 5\% as the temperature rises approximately by $0.13 \mathrm{C}$ per decade. By 2020 , the south asian countries will see rise in maximum and minimum temperature of $1.54 \mathrm{c}$ and $1.08 \mathrm{c}$ during rabi season. (Bhusal et al., 2017). The central and peninsular region of India faces heat stress and north western region affected by terminal heat stress due to late sowing conditions. (Sharma et al., 2014). On the other hand, the southern great plains of America reported temperatures of 32-35c during grain filling duration. The high temperature accounts for phenotypic changes as well. For each degree rise in temperature, it is reduced by 6\%. According to (Mason et al. 2010), if the wheat grain growth period coincides with high temperatures, it can reduce grain yield by up to $28.3 \%$. Heat stress accelerates the wheat growth phase and shortens the grain filling duration leads to lower yield. It creates alteration in traits like morpho-physiological, agronomic, and yield-related characters. The morpho-physiological characters like canopy temperature and chlorophyll are easy to detect with handheld meters and handy for breeders. These traits have a great correlation with yield under high temperatures. Criteria for the selection of heat-tolerant genotypes 
bioRxiv preprint doi: https://doi.org/10.1101/2021.06.17.448834; this version posted June 17, 2021. The copyright holder for this preprint

must be rapid and cheap in the evaluation and should also allow for the screening of a high number of plants in a short period (Mitra 2001; Araus et al. 2002). To overcome this abiotic insult, breeding materials should be utilized which helps in understanding the genotype $\mathrm{x}$ environment relationship. The breeding population like doubled haploids, which can be utilized to deliver thermo-tolerant lines. It is an important tool for plant genome mapping. Molecular marker is prerequisite to identify quantitative trait loci (QTL) associated with stress tolerance (Campbell et al. 2003; Pinto et al. 2010). To find the stability of marker-QTL in different environments and genetic background is a tedious job (Yang et al. 2007). But, newer and evolving software programmes has lead us to provide more reliable results and helps us in understanding the complexity between genes and the phenotypic traits. Therefore, several efforts have been undertake to modify this crop to tolerate heat. In view of the facts mentioned above, the present study was undertaken to develop marker-QTL linkage involved in heat stress in the DH population. Morpho-physiological characterization of the doubled haploid lines considering heat stress. To discuss the impact of high-temperature stress on wheat and traits associated with heat tolerance which would help formulate management strategies for wheat yield improvement under hightemperature stress and breeding for high-temperature tolerant varieties.

\section{Materials and methods}

\section{Plant material}

A doubled haploid population, derived from a cross between PBW343 (heat susceptible) and IC252874 (heat tolerant) (Fig 1) was sown in four experiments over two field seasons. The population contained 166 individuals. The plants were planted in alpha lattice design with three replications. Proper agronomic practices and irrigation were provided to avoid yield reduction during the crop cycle. The development of the DHs was done in the Washington State University, Pullman, USA, and evaluation was carried out at the research farm of

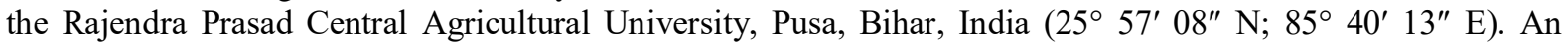
offseason facility at the Research station of Punjab Agricultural University, Keylong, Himachal Pradesh, India, was utilized for seed multiplication. .

\section{Data collection and evaluation for heat stress}

To expose the plants to different levels of temperatures at the time of grain filling, the crop was sown during the second week of November and during the first week of January. Then average ambient temperatures during the grain growth phase between anthesis to physiological maturity were 25.5 and $25^{\circ} \mathrm{C}$ when sown in November and 32 and $32.8 .0^{\circ} \mathrm{C}$ when sown in January in 2017-2018 and 2018-2019, respectively. As differences in days to heading in selected genotypes ranged from 8 to 14 days, previous observations were used for staggered sowing to ensure synchrony in flowering and thus nearly same level and magnitude of exposures to ambient temperatures during grain filling across the genotypes. Irrigation was provided to the crop at five growth stages (at crown root initiation Zadok, GS 21; tiller completion Zadok, GS 29; late jointing Zadok, GS 36; flowering Zadok, GS 61; and milk stage Zadok, GS 75) and six (at crown root initiation Zadok, GS 21; tiller completion Zadok, GS 29; late jointing Zadok, GS 36; flowering Zadok, GS 61; milk Zadok, GS 75; and dough stage Zadok, GS 85) both in timely and late-sown experiments during the crop season in both the years to maintain optimum soil moisture. Weeds were removed manually. To avoid border effects, plants at the centre of each plot were chosen for collecting all the data. The data were recorded for total ten characters viz. heading, was calculated as the length of the period between seedling emergence and the time that $50 \%$ of spikes emerged from leaf sheath, maturity was measured with $75 \%$ yellowness, plant height and peduncle length was measured on a random sample of five plants in each plot as the distance from the soil surface to the tip of the spike awns excluded at harvest time $(\mathrm{cm})$. Total leaf chlorophyll content (SPAD index) estimated using spad-502 chlorophyll meter (spad-502 plus, Konica Minolta, Kearney, NE, USA), during the flowering stage. Canopy temperatures were measured using a handheld infrared thermometer (KM 843, Comark Ltd., Hertfordshire, UK) with a field view of $100 \mathrm{~mm}$ to $1000 \mathrm{~mm}$. Canopy temperatures data were taken from the same side of each plot at $1 \mathrm{~m}$ distance from the edge and approximately $50 \mathrm{~cm}$ above the canopy. CT values were recorded at three growth stages (GS55, GS65, and GS83). Plants at the centre of each plot were selected to count the number of tillers at the growth stage, GS85; (Zadoks et al. 1974). Both shoots and roots were collected for biomass determination. Readings were made between 1300 and $1500 \mathrm{~h}$ on sunny days. Thousand-grain weight (TGW in g) and grain yield (GY in g) was calculated by weighing grains of harvested plants from an area of $2 \mathrm{~m}^{2}$ in each plot excluding border effect (Sayre et al. 1997).

\section{Statistical analysis}


bioRxiv preprint doi: https://doi.org/10.1101/2021.06.17.448834; this version posted June 17, 2021. The copyright holder for this preprint

Analysis of variance and least square means of all traits were estimated using the statistical procedure Proc. Mixed of SAS version 8.2 (SAS Inst. Inc. 1999).Values of means, medians, standard deviation, Variance, Coefficient of variation, minimum, maximum, and range showing the distribution of phenotypic data for different traits were determined using $\mathrm{R}$ software. Correlation coefficients between the traits for the trials were performed using $\mathrm{R}$ software. A stepwise regression analysis-based clustering was performed. The differences in trait response between the normal and stress conditions for phenotypic factors corresponding under stress were considered to perform cluster analysis using pair group distance with Euclidean distance measures. The dendrogram was constructed using the R software (version 3.5.1).

\section{Genotyping, construction of linkage map, and QTL mapping}

Few seeds of parents and DHs were germinated on filter paper in dark and coleoptiles were used to extract DNA following the recommended DNA extraction method (http://www.triticarte.com.au/content/DNA-prepa ration.html. The thermocycling programme consisted of an initial denaturation at $94^{\circ} \mathrm{C}$ for $3 \mathrm{~min}$, followed by 30 cycles of $30 \mathrm{~s}$ at $94^{\circ} \mathrm{C}, 30 \mathrm{~s}$ at $50 / 65^{\circ} \mathrm{C}, 30 \mathrm{~s}$ at $72^{\circ} \mathrm{C}$ and a final cycle of $2 \mathrm{~min}$ at $72^{\circ} \mathrm{C}$ in Thermal Cycler (Sharma et al. 2016). A total of 200 SSR markers were screened for polymorphism between the parents and the resulting polymorphic markers were used to screen the DHs. Profiles of polymorphic SSR markers were scored visually by coding PBW343 alleles as "A" whereas IC252874 alleles were scored as "B". While heterozygote individuals are scored as " $\mathrm{H}$ ". Missing bands were scored as 'NA'.A consensus map (Somers et al. 2004) was used to select microsatellite/simple sequence repeat. Allele bands were visualized on $2 \%$ agarose gels. (Fig2) For the construction of linkage maps, a set of 61 SSRs (gwm, wmc, swm, barc, and cfd) spanning on eight wheat chromosomes (1A, 1D, 2B, 2D, 3B, 4D, 5B, and 6D) were deployed during the present investigation. Out of 200 SSR markers, 12 markers were not amplified at all and 61 SSR markers that were polymorphic between the parental genotypes of the DH mapping population were used for the preparation of the linkage map. The genotyped data of the DH population was used to generate a linkage map using software MapDisto 2.1.7.1.

The Kosambi mapping function and interval position type was used for the conversion of recombination frequency into the genetic distance. QTL analysis was performed using QTL Cartographer v2.5 (Wang et al., 2010). In the CIM method, forward regression with five background markers, a window size of $10.0 \mathrm{cM}$, and a walking speed of $2 \mathrm{cM}$ were used in the software Windows QTL Cartographer 2.5 (Wang et al. 2010). The trait setting for Composite interval mapping (CIM) was done using model 6 and used to determine likely QTL positions and a threshold of 1,000 permutation test at $\mathrm{P}=0.05$. The putative QTLs were defined as two or more linked markers associated with a trait at LOD > 3.0. The suggestive QTLs were defined as QTLs where two or more linked markers were detected at $2.0<$ LOD < 3.0 (McIntyre et al. 2010). Here, The LOD value was set as minimum LOD value 2.0, to keep consider suggestive and minor QTL as well.

\section{Result}

\section{Phenotypic assessment for heat tolerance}

Very contrasting differences were found in parental lines for plant height and grain yield under stress condition. The heat-tolerant parent, IC252874, showed non-significant reduction for all yield components, whereas plant height was found highly reduced (20\% and $19.2 \%)$ under late-sown condition in both the years. On the contrary, the heat-sensitive parent, PBW 343, showed significant reduction in plant height (24\% and 21\%), CT (27\% and $29 \%)$ and GY (40\% and 33\%) with little reduction in SPAD under late-sown condition in both the years. The heat-tolerant genotype IC252874 showed an increase in the DM with a shorter growth period, whereas the heat-sensitive genotype PBW 343 showed medium days to maturity. It was interesting that there was no significant reduction in TGW in both parents under terminal heat stress in late-sown condition as compared to timely sown. A significant reduction in DM (18\% and 19.2\%), CT (19\% and $21 \%)$, PH (16\% and $14.3 \%)$ and GY (33\% and 30.1\%) was observed in DH population under heat stress across the years. Mean values were normally distributed within the DH population due to the presence of a large number of transgressive segregants (Table 1). The doubled haploid lines along with the parents were subjected to genetic divergence analysis differed significantly with regard to the above studied characters and displayed marked divergence and grouped into eight clusters following Euclidean method (Table). Cluster I is the largest cluster with sixty one DH lines and a parent, PBW 343 viz. DH 61, DH 60, DH 45, DH 48, DH 50, DH 53, DH 54, DH 57, DH 63, DH 64, DH 67, DH 73, DH 74, DH 78, DH 80, DH 89, DH 91, DH 112, DH 120, DH 123, DH 127, DH 128, DH 133, DH 134, DH 135, DH 138, DH 142, DH 145, DH 146, DH 152, DH 159, DH 160, DH 161, DH 163, DH 164, DH 166, DH 24, DH 25, DH 26, DH 27, DH 28, DH 29, DH 31, DH 32, DH 34, DH 35, DH 36, DH 38, DH 39, DH 
bioRxiv preprint doi: https://doi.org/10.1101/2021.06.17.448834; this version posted June 17, 2021. The copyright holder for this preprint (which was not certified by peer review) is the author/funder, who has granted bioRxiv a license to display the preprint in perpetuity. It is made available under aCC-BY-NC-ND 4.0 International license.

43, DH 1, DH 6,PBW, DH 8, DH 9, DH 10, DH 12, DH 13, DH 15, DH 17, DH 59, DH 72 followed by Cluster VI having thirty four DH lines namely DH 95, DH 121, DH 124, DH 100, DH 49, DH 56, DH 141, DH 58, DH 139, DH 33, DH 65, DH 69, DH 157, DH 52,DH 155, DH 85, DH 23, DH 46, DH 68, DH 66, DH 86, DH 84, DH 158, DH 14, DH 20, DH 21, DH 30, DH 83, DH 147,DH 153, DH 154, DH 22, DH 55, DH 75. Cluster V, VII and VIII has twenty five, seventeen and twenty one DH lines while Cluster II, III and IV accounted for five, eight and one DH lines. (Fig 3)

\section{Weather condition and phenotypic summary}

The late-sown heat experiments were the hottest in terms of average minimum and maximum temperatures during vegetative growth and grain fill, and had the highest number of days with temperature (28 and 34C). The meteorological data for both the cropping season 2017-2018 and, 2018-2019 is given in (Table 2). Analysis of variance showed significant genotypic variance present in the DHs for heat tolerance (Table 3). For the eight studied traits, values of correlation coefficients based on data pooled over Normal sowing and Late sowing conditions are presented in (Figure 4). Each of the traits showed a positive and significant correlation across year, confirming the stability of these measurements of high temperature tolerance. Both in the NS and LS conditions, CT was non-significantly correlated to DH, The magnitudes of correlation of CT with other traits were higher under LS condition relative to those in the NS condition. The correlation of GY with TGW was positive and significant, while with CT, it was negative. The correlation of SPAD with GY and TGW was low to moderate.

\section{Molecular characterization of DH population and genetic linkage map construction}

A set of 200 SSR primers were used to detect polymorphism between parental genotypes, out of Which, 61 SSRs were polymorphic. The sixty-one SSRs showed a good fit to the 1:1 segregation ratio in the DH mapping population. The linkage maps spanned 3,314.64 cM coverage. The maximum number of polymorphic markers were found on 2B with fourteen markers while lowest being two on $6 \mathrm{D}$ chromosome. The linkage map developed using 61 polymorphic markers and $166 \mathrm{DHs}$ population was further utilized to analyze QTLs. The genome of DHs is composed of 61per cent of PBW 343 whereas 23.4 per cent of IC and remaining is 9 percent, constitute the heterozygous, distorted and missing values. The linkage maps with identified QTLs in PBW343/IC252874 DHs were presented in (Fig. 5)

\section{QTL mapping for the heat stress tolerance}

A total of 12 QTL were detected for eight different traits using Composite Interval Mapping (CIM) under Normal sown and late sown condition during both the crop seasons 2017-2018 and 2018-19 (Table 4). These were located on 8 different chromosomes, 1A, 1D, 2B, 2D, 3B, 4D, 5B, and 6D. The LOD scores of identified QTLs varied from 3.02 (DM-4D) to 21.35 (CT-1A) during 2017-18 and 2018-19 explaining 6.72\% and 25.61\% phenotypic variance, respectively (Fig 6). A minimum of 1 QTL were available each for, DHE, TGW and CT, 3 QTLs were available for DM and SPAD on an average. A maximum of 4 QTLs were detected for GY under Normal and late sown conditions, respectively. QTLs were identified both in normal sown (2 QTLs) and late sown conditions (10 QTLs). In this study, QTLs for biomass and plant height were not found either in normal or late-sown conditions across the year. The absence of QTLs for phenological traits indicated that there were no confounding effects between environment and phasic development.

\section{Discussion}

To combat the climatic insult in agriculture, molecular resources are used to develop stress resilient crops. QTL mapping is a best known approach to unravel the molecular information linked with the plants phenotype under various environmental (stress) conditions. Several QTL mapping studies in wheat under abiotic stress conditions involved mapping populations such as RILs (Pinto et al. 2010; Mason et al. 2011; Paliwal et al. 2012), doubled haploids (Tiwari et al. 2013) and segregating F2 and F3 populations (Gupta et al. 2015). In present investigation, a doubled haploid population is used to undertake this study. The ability to manage different sowing conditions created two distinct environmental treatments for the PBW343/IC252874 doubled haploid population. The phenotypic response to normal and late sown conditions within the population has been unraveled by QTL mapping. The late sown condition was the lowest yielding on an average for the population and it resulted into shortest ear emergence time, caused due to higher temperature and longer day length. Due to the longer growing season under late sown condition, it was warmer. During flowering time, it was more prone to abiotic stress such as high temperature (Dolferus et al. 2011; Gibson and Paulsen 1999). There was a significant variation present in the parents of the DH population for the studied traits suggesting genetic 
bioRxiv preprint doi: https://doi.org/10.1101/2021.06.17.448834; this version posted June 17, 2021. The copyright holder for this preprint (which was not certified by peer review) is the author/funder, who has granted bioRxiv a license to display the preprint in perpetuity. It is made available under aCC-BY-NC-ND 4.0 International license.

diversity among both the parents. Analysis of variance showed significant $(\mathrm{p}<0.01)$ main effects due to genotypes for all studied traits present in the DHs for heat tolerance. The frequency distribution of DHs exceeded beyond those of the parents reveals the presence of transgressive segregation. As observed by Yang $e t$ al. 2002, this suggested that the parents contributed different genes for heat tolerance and that traits were not simply inherited. Rieseberg et al. 1999 suggested complementary gene action as a primary source of transgression and Bhusal et al., 2017 observed the RILs population also showed transgressive segregation; exceeding both the parents for traits indicated genes with positive and negative effects were dispersed between parents.

According to the above weather forecast, the late sown condition showed terminal heat stress towards the crop over both the year. The mean minimum and maximum temperatures, under late sown condition were higher than the normal sown condition during 2017-2018 and 2018-2019 crop seasons. However, heat stress during 2018-2019 crop seasons was comparatively more than 2017-2018.

Phenotypic correlation between the traits explains that DHE was negatively correlated with GY under late sown condition.The correlations obtained in present study are in agreement with the previous reports under heat stress. Days to maturity was significantly correlated with, TGW, GY under control and late-sown conditions. Phenotypic correlations of TGW with YLD were significant and positive (0.15-0.89) (Tahmasebi et al. 2016). Both DHE and DMA had negative and significant genotypic correlations with GY. Negative phenotypic correlations were found between DHE and TGW. PHE showed positive genetic correlations with DHE, DMA, but its correlations with CT, was negative. Themorpho-physiological characters such as canopy temperature (Bahar et al., 2008), and cholorophyll content (SPAD) (Yıldırım et al., 2011) provides genetic gain to wheat. To characterize the mapping populations and genotypes under heat stress condition, CT has been widely used (Tiwari et al. 2012; Reynolds et al. 1997). In this study, the tolerant parent displayed higher value for CT in late sown conditions which indicated a better cooling capacity during grain filling under higher temperature. Similarly, reported by Reynolds et al. 1994 and Ayeneh et al. 2002. The degree of cooling reflects the rate of evapotranspiration on the surface of the plant canopy (Ayeneh et al. 2002) and gains in yield owing to the positive effect of reduced canopy temperature (Reynolds et al. 2007). Ayeneh et al. 2002 reported that canopy temperature can be used as a tool in the selection of wheat targeted for tolerance to heat stress. We have found positive correlations of canopy temperature with grain yield. According to Reynolds et al., 1994, Fischer et al., 1998, Phenotypic correlations of CT with grain yield were occasionally positive. However, Saint Pierre et al. 2010 reported significant negative phenotypic correlation $(r=-0.34$ to $-0.75, P \backslash 0.001)$ between canopy temperature and grain yield under drought conditions in wheat. On the other hand, SPAD index was not significantly correlated and associated with GY in both the normal and late sown conditions. Similarly, Tahmasebi et al. 2016 reported that there was no consistent association between SPAD and GY under different environments. On the other hand, Pinto et al. 2010 observed, tolerance to heat in field crops, including bread wheat, is associated with a variety of physiological, biochemical, and morphological traits. In this study, three hundred and two hundred SSR primer pairs representing eight chromosomes of wheat were used to detect polymorphism between the parental genotypes, IC252874 (heat tolerant) and PBW343 (heat susceptible). Out of the 200 SSR primer pairs, polymorphism between the parents was detected by 61 (17.3\%) SSRs. Similarly, Pandey et al. 2013 screened the parent, Raj 4014, and WH 730 with three hundred SSR markers. Out of those SSR markers tested, 15\% were found polymorphic and Bhusal et al., 2017 used three hundred and eighty SSR primer, screened with parents HD2808 and HUW510 to detect polymorphism. Of these, $14.2 \%$ of markers revealed parental polymorphism. In this present study, QTL analysis allowed mapping of as many as 12 QTLs (NS and LS conditions) for morpho-physiological and yield traits suggesting that the genetic control of these traits in wheat is complex. This was also supported by the continuous distribution in the component traits of heat tolerance. The findings of earlier studies for identification of QTL also suggested complex genetic control of yield and related traits (McIntyre et al. 2010; Pinto et al. 2010; Bennett et al. 2012a; Bennett et al. 2012b; Kadam et al. 2012; Lopes et al. 2012). Use of morpho-physiological traits and tools like CT and SPAD in combination with QTL mapping provides basic understanding and can serve as useful criterion in selection of heat tolerant genotypes (Harikrishna et al., 2020).

Composite interval mapping revealed genomic regions on chromosomes 3B harbored a major QTL for GY, will be vital for genetic improvement perspective of wheat for heat stress using marker assisted selection from the yield point of view. This QTL was detected both under NS and LS conditions, suggesting this QTL is more stable and can be used for selection of yielding genotypes for testing under both conditions. This QTL explained $11.84 \%$ to $21.24 \%$ of phenotypic variance under NS and LS conditions. However, Other published QTL effects were, Grain yield and plant height in stressed and other environments in a durum wheat Kofa $\times$ Svevo RIL population, was also associated with Xgwm493 (Maccaferri et al., 2008). The chromosome no. 5B also carried a QTL for GY and the marker associated was gwm335. Mohammadi et al., 2008 reported a marker 
bioRxiv preprint doi: https://doi.org/10.1101/2021.06.17.448834; this version posted June 17,2021 . The copyright holder for this preprint (which was not certified by peer review) is the author/funder, who has granted bioRxiv a license to display the preprint in perpetuity. It is made available under aCC-BY-NC-ND 4.0 International license.

gwm133 directly linked to heat tolerance whereas gwm335 was only 6.2cM away from it. So, gwm335 could be useful in carrying heat tolerance gene as well. QTLs for days to heading, days to maturity and grain yield under late sown condition were also detected on chromosome 1D. The LOD score of these QTLs was above 3.0 while, the phenotypic variations of these QTLs were varied from 6.24 to $19.32 \%$. Similarly, Tahmasebi et al. 2016 found that 1D-barc0062 was linked to QTL for DHE and DMA. The M-QTL located on chromosome 1D explained $23.7 \%$ of DHE variation, respectively. Zikhali et al. 2014 recently validated a major Eps QTL in the barc62 marker of 1D using wheat near isogenic lines (NILs). In our study, the QTL identified at the same marker possibly is related to the Eps genes. One QTL was found to be localized on 2B chromosome for SPAD, accounted for a phenotypic variance of 10.48-13.43\%. Similarly, Hassan et al., 2018 reported two QTLs associated with GY and SPAD on chromosome 2B were also co-located. These common genomic regions for different traits can be explained by the linkage between two or more genes or the pleiotropic effect of one gene. A QTL for TGW was found on 6D chromosome under late sown condition and showed a phenotypic variance of 6.43\%-8.45\% Similarly, Bhusal et al., 2017 also reported a QTL for TGW, associated with barc21, which explained a phenotypic variance of $13.24 \%$ but under non-stressed condition. It was interesting to note that the QTLs detected under heat-stressed conditions for SPAD on chromosome 1A also co-localized with the QTL for CT under late sown conditions. Co localization of QTLs is common in wheat and is the hot spot for networking of complex traits such as yield. The significance of this has been reported for heat stress-related traits in wheat (Mason et al. 2010, Pinto et al. 2010, Paliwal et al. 2012). The clusters of QTLs in a few genomic regions increase the validity and utility value of the detected QTLs. In the present study, common genomic regions found for CT and SPAD variations indicated that a group of linked and co-located QTLs on chromosome 1A and affected phonological and yield-related traits. This stability in QTL across the year could be attributed to high stability for these traits and precision in phenotyping. The authors realize that it is important to observe the performance of this population with more multi-location trial and subject it to the SNP platform for the sake of accuracy and precision.

\section{References}

Hassan FSC, Solouki M, Fakheri BA et al (2018) Mapping QTLs for physiological and biochemical traits related to grain yield under control and terminal heat stress conditions in bread wheat (Triticum aestivum L.). Physiol Mol Biol Plants 24:1231-1243.

Zikhali M, Leverington-Waite, Fish M L, Simmonds J, Orford S, Wingen LU et al (2014) Validation of a1DLearliness per se (eps) flowering QTL in bread wheat (Triticum aestivum L.). Mol. Breed. 94: 1-11.

Maccaferri M, Sanguineti MC, Corneti S, Ortega JLA, Salem MB, Bort J et al (2008) Quantitative trait loci for grain yield and adaptation of durum wheat (Triticum durum Desf.) across a wide range of water availability. Genetics. 178:489-511.

Lopes MS, Reynolds MP, Jalal-Kamali MR, Moussa M, Feltaous Y, Tahir ISA, Barma N, Vargas M, Mannes Y and Baum M (2012). The yield correlations of selectable physiological traits in a population of advanced spring wheat lines grown in warm and drought environments. Field Crops Res 128: 129136.

Kadam S, Singh K, Shukla S, Goel S, Vikram P, Pawar V, Gaikwad K, Khanna- Chopra R and Singh N (2012) Genomic associations for drought tolerance on the short arm of wheat chromosome 4B. Funct. Integr. Genomics 12: 447-464.

Bennett D, Izanloo A, Edwards J, Kuchel H, Chalmers K, Tester M, Reynolds M, Schnurbusch T and Langridge P (2012a) Identification of novel quantitative trait loci for days to ear emergence and flag leaf glaucousness in a bread wheat (Triticum aestivum L.) population adapted to southern Australian conditions. Theor. Appl. Genet 124: 697-711.

Bennett D, Reynolds M, Mullan D, Izanloo A, Kuchel H, Langridge P and Schnurbusch T (2012b) Detection of two major grain yield QTL in bread wheat (Triticum aestivum L.) under heat, drought and high yield potential environments. Theor. Appl. Genet 125: 1473-1485.

McIntyre CL, Mathews L, Ratty A, Chapman SC, Drenth J,, Ghaderi M, Reynolds M and Shorter R (2010) 
bioRxiv preprint doi: https://doi.org/10.1101/2021.06.17.448834 this version posted June 17, 2021. The copyright holder for this preprint (which was not certified by peer review) is the author/funder, who has granted bioRxiv a license to display the preprint in perpetuity. It is made available under aCC-BY-NC-ND 4.0 International license.

Molecular detection of genomic regions associated with grain yield and yield- related components in an elite bread wheat cross evaluated under irrigated and rainfed conditions. Theor. Appl. Genet 120: 527541.

Reynolds M P, Nagarajan S, Razzaque MA and Ageeb OAA (1997) Using canopy temperature depression to select for yield potential of wheat in heat-stressed environment. Wheat Program Special Report, CIMMYT, Mexico 42.

Tiwari C, Wallwork H, Dhari R, Arun B, Mishra VK and Joshi A K (2012) Exploring the possibility of obtaining terminal heat tolerance in a doubled haploid population of spring wheat (Triticum aestivum L.) in the eastern Gangetic plains of India. Field Crops Res 135: 1-9.

Yıldırım M, Kılıc H, Kendal E, Karahan T (2011) Applicability of chlorophyll meter readings as yield predictor in durum wheat. J. Plant Nutr 34(2): 151-164.

Bahar B, Yildirim M, Barutcular C, Genc I (2008) Effect of canopy temperature depression on grain yield and yield components in bread and durum wheat. Notulae Botanicae Horti Agrobotanici Cluj-napoca 36(1): 34-37.

Ortiz R, Sayre K D, Govaert B, Gupta R, Subbarao GV, Ban T and Reynolds M (2008) Climate change: Can wheat beat the heat. Agric. Ecosyst. Environ 126(1): 46-58.

Paliwal R, Röder MS, Kumar U, Srivastava JP and Joshi AK (2012) QTL mapping of terminal heat tolerance in hexaploid wheat (T. aestivum L.). Theor. Appl. Genet 125(3): 561-575.

Gupta M, Chawla V, Garg P, Yadav NR and Sharma B (2015) Genetic analysis of yield and heat stress related traits in wheat (Triticum aestivum L. em. Thell) using microsatellite markers. J. Nat. Appl. Sci 7(2): 739-744.

Harikrishna, Singh GP, Jain N, Singh PK, Sai Prasad SV, Ambati D, Das TR, Kumar A, Bhat JA, Bellundagi A, Vijay Priyanka, Sinha N, Mishra PC, Misra SC and Prabhu KV (2016) QTL mapping for heat tolerance related traits using backcross inbred lines in wheat (Triticum aestivum L). Indian J. Physiol 21: 576582

Hertel TW, Burke MB, Lobell DB (2010) The poverty implications of climate-induced crop yield changes by 2030. Glob Environ Change 20(4): 577-585.

Sharma P, Sareen S, Saini M, Verma A, Tyagi BS, Sharma I (2014)Assessing genetic variation for heat tolerance in synthetic wheat lines using phenotypic data and molecular markers. Aust J Crop Sci $8: 515-522$.

Tiwari C, Wallwork H, Kumar U, Dhari R, Arun B, Mishra VK and Joshi AK (2013) Molecular mapping of high temperature tolerance in bread wheat adapted to the Eastern Gangetic Plain region of India. Field Crops Res 154: 201-210.

Bhusal N, Sarial AK, Sharma P, Sareen S (2017) Mapping QTLs for grain yield components in wheat under heat stress. Plos ONE 12 (12)

Zadoks JC, Chang TT, Konzak CF (1974) A decimal code the growth stages for cereals. Weed Research 14: $415-421$.

Sayre K, Rajaram S, Fischer R (1997) Yield potential progress in short bread wheat in northwest Mexico. Crop Science 37: 36-42

Fischer RA, Maurer R (1978) Drought resistance in spring wheat cultivars. I: grain yield responses. Australian Journal of Agricultural Research 29: 897-907.

Dolferus R, Ji XM, Richards RA (2011) Abiotic stress and control of grain number in cereals. Plant Sci $181: 331-341$ 
bioRxiv preprint doi: https://doi.org/10.1101/2021.06.17.448834; this version posted June 17, 2021. The copyright holder for this preprint (which was not certified by peer review) is the author/funder, who has granted bioRxiv a license to display the preprint in perpetuity. It is made available under aCC-BY-NC-ND 4.0 International license.

Gibson LR, Paulsen GM (1999) Yield components of wheat grown under high temperature stress during reproductive growth. Crop Sci 39:1841-1846

Saghai-Maroof MA, Soliman KM, Jorgensen R, Allard RW (1984) Ribosomal DNA spacer-length polymorphisms in barley: Mendelian inheritance, chromosomal location, and population dynamics. Proceedings of the National Academy of Sciences 81(24): 8014-8018.

Somers DJ, Isaac P, Edwards K, (2004) A high-density microsatellite consensus map for bread wheat (Triticum aestivum L.). Theoretical applied genetics 109(6): 1105-1114.

Sharma P, Sareen S, Saini M, Shefali (2016) Assessing genetic variation for heat stress tolerance in Indian bread wheat genotypes using morpho-physiological traits and molecular markers. Plant Genetic Resources 1-9.

Wang S, Basten CJ, Zeng ZB (2010). Windows QTL Cartographer 2.5. Department of statistics, North Carolina State University, Raleigh, NC.

Sourdille P, Cadalen T, Guyomarc'h H, Snape JW, Perretant MR, Charmet G, Boeuf C, Bernard S, Bernard M (2003) An update of the Courtot $\times$ Chinese Spring intervarietal molecular marker linkage map for the QTL detection of agronomic traits in wheat. Theoretical applied genetics 106: 530-538.

Yang J, Sears RG, Gill BS, Paulsen GM, (2002) Quantitative and molecular characterization of heat tolerance in hexaploid wheat. Euphytica 126(2): 275-282.

Rieseberg LH, Archer MA, Wayne RK (1999) Transgressive segregation, adaptation, and speciation. Heredity 83: 363-372.

Mohammadi VA, Zali A, Bihamta MR (2008) Mapping QTL for heat tolerance in wheat. Journal of Agriculture, Science and Technology 10: 261-267.

Pinto RS, Reynolds MP, Mathews KL, McIntyre CL, Olivares- Villegas JJ, Chapman SC (2010). Heat and drought adaptive QTL in a wheat population designed to minimize confounding agronomic effects. Theoretical applied genetics. 121: 1001-1021.

Yang XH, Guo YQ, Yan JB, Zhang J, Song TM, Rocheford T, Li JS (2010) Major and minor QTL and epistasis contribute to fatty acid composition and oil content in high-oil maize. Theoretical applied genetics 120: $665-678$.

Barakat MN, Al-Doss AA, Elshafei AA, Moustafa KA (2011). Identification of new microsatellite marker linked to the grain filling rate as an indicator for heat tolerance genes in F2 wheat population. Australian Journal of Agricultural Science 5: 104-110.

Mason RE, Mondal S, Beecher FW, Pacheco A, Jampala B, Ibrahim AMH, Hays DB (2010). QTL associated with heat susceptibility index in wheat (Triticum aestivum L.) under short-term reproductive stage heat stress. Euphytica. 174: 423-436.

Mason RE, Mondal S, Beecher FW, Hays DB (2011). Genetic loci linking improved heat tolerance in wheat (Triticum aestivum L.) to lower leaf and spike temperatures under controlled conditions. Euphytica. 180: 181194.

Reynolds M, Balota M, Delgado M, Amani I, Fischer R (1994) Physiological and morphological traits associated with spring wheat yield under hot, irrigated conditions. Functional Plant Biology 21: 717-730

Ayeneh A, Ginkel M, Reynolds MP, Ammar K (2002) Comparison of a leaf, spike, peduncle, and canopy temperature depression in wheat under heat stress. Field Crops Research 79: 173-184.

Reynolds MP, Hobbs PR, Braun HJ (2007) Challenges to international wheat improvement. Journal of Agricultural Science 145: 223-227. 
bioRxiv preprint doi: https://doi.org/10.1101/2021.06 17.448834· this version posted June 17, 2021. The copyright holder for this preprint (which was not certified by peer review) is the author/funder, who has granted bioRxiv a license to display the preprint in perpetuity. It is made available under aCC-BY-NC-ND 4.0 International license.

Saint PC, Crossa J, Manes Y, Reynolds MP (2010). Gene action of canopy temperature in bread wheat under diverse environments. Theoretical applied genetics 120: 1107-1117

Tahmasebi S, Heidari B, Pakniyat H, McIntyre CL (2016) Mapping QTLs associated with agronomic and physiological traits under terminal drought and heat stress conditions in wheat (Triticum aestivum L.). Genome 60: $26-45$

Pinto RS, Reynolds MP, Mathews KL, McIntyre CL, Olivares-Villegas JJ, Chapman SC (2010) Heat and drought adaptive QTL in a wheat population designed to minimize confounding agronomic effects. Theoretical applied genetics 121: 1001-1021

Pandey GC, Jagadish RJ, Sareen S, Siwach P, Singh NK, Tiwari R (2013). Molecular investigations on grain filling rate under terminal heat stress in bread wheat (Triticum aestivum L.). African Journal of Biotechnology 12(28): 4439-4445.

Sage RF, Kubien DS (2007) The temperature response of $\mathrm{C}_{3}$ and $\mathrm{C}_{4}$ photosynthesis. Plant Cell Environment 30: 1086-1106.

Nash D, Miyao M, Murata N (1985) Heat inactivation ofoxygen evolution in photosystem II particles and itsacceleration by chloride depletion and exogenous manganese. Biochimica et Biophysica Acta 807: 127-133

Mason RE, Hays DB, Mondal S, Basnett BR, Ibrahim AMH (2013) QTL for yield components and canopy temperature depression in wheat (Triticum aestivum L.) under late sown field conditions. Euphytica. 194: 243259.

Mitra J (2001) Genetics and genetic improvement of drought resistance in crop plants. Current Science. 80: $758-763$.

Araus JL, Slafer GA, Reynolds MP, Royo C (2002) Plant breeding and drought in C-3 cereals: What should we breed for? Annals of Botany 89: 925-940.

Campbell BT, Baenziger PS, Gill KS, Eskridge KM, Budak H, Erayman M (2003) Identification of QTLs and environmental interactions associated with agronomic traits on chromosome 3A of wheat. Crop Sciences 43: $1493-1505$.

Yang J, Zhu J, Williams RW (2007) Mapping the genetic architecture of complex traits in experimental populations. Bioinformatics 23: 1527-1536.

\section{Declaration- NA}

Acknowledgement/Funding - The work was supported by United States Agency for International Development-Biotechnology Industry Research Assistance Council (Reference number: BIRAC/TG/USAID/08/2014) and Acknowledgement to the Department of Agricultural Biotechnology and Molecular Biology, Rajendra Prasad Central Agricultural University, Pusa, Bihar

Conflicts of interest- There is no conflict of interest between authors 
bioRxiv preprint doi: https://doi.org/10.1101/2021.06 17.448834 t this version posted June 17, 2021. The copyright holder for this preprint (which was not certified by peer review) is the author/funder, who has granted bioRxiv a license to display the preprint in perpetuity. It is made available under aCC-BY-NC-ND 4.0 International license.

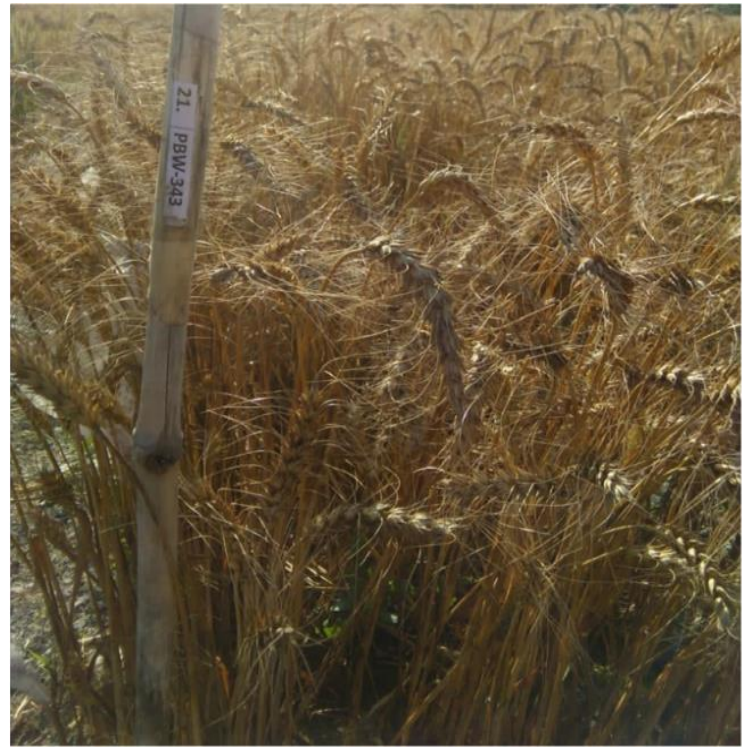

A

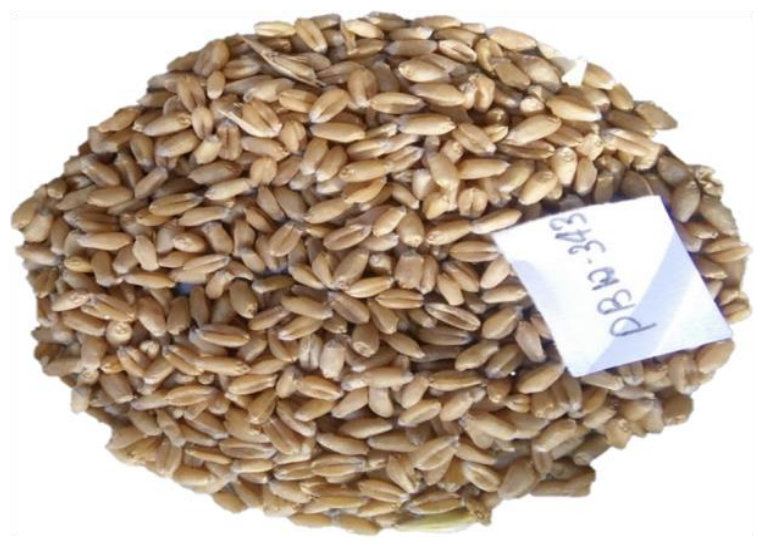

$\mathrm{C}$

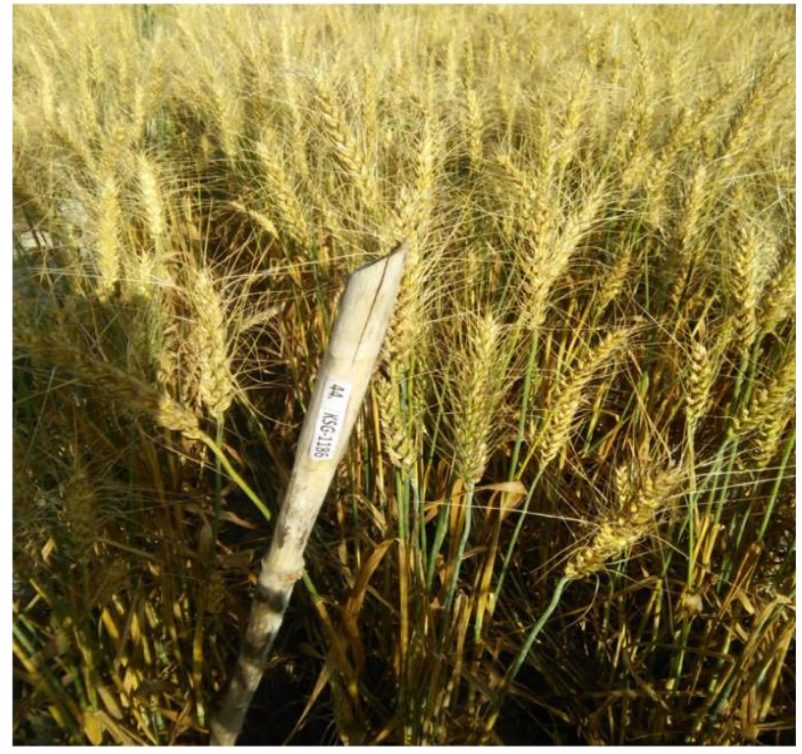

B

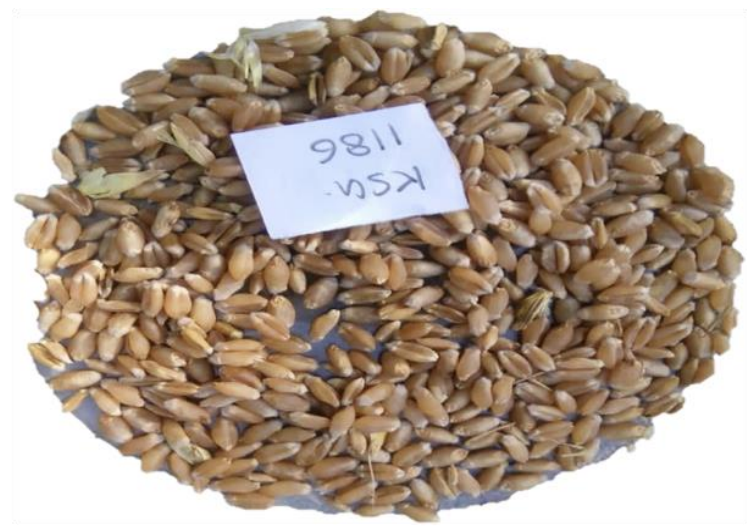

$\mathrm{D}$

Fig 1: A. PBW343 (Heat susceptible parent) B. IC252874 (Heat Resistant parent) C. PBW343 Seeds D. IC252874 
bioRxiv preprint doi: https://doi.org/10.1101/2021.06.17.448834 this version posted June 17 2021. The copyright holder for this preprint (which was not certified by peer review) is the author/funder, who has granted bioRxiv a license to display the preprint in perpetuity. It is made available under aCC-BY-NC-ND 4.0 International license.

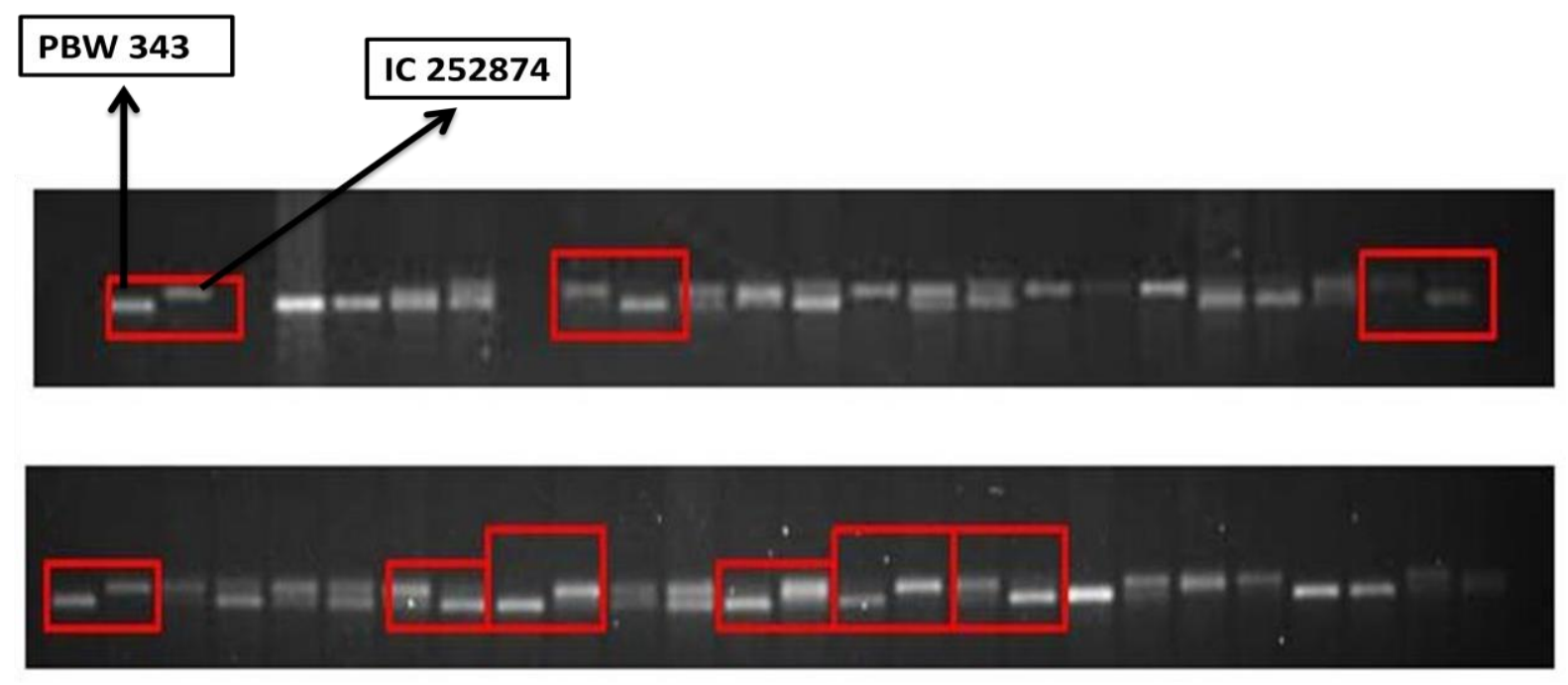

Fig 2: Parental polymorphism between PBW343 and IC252874

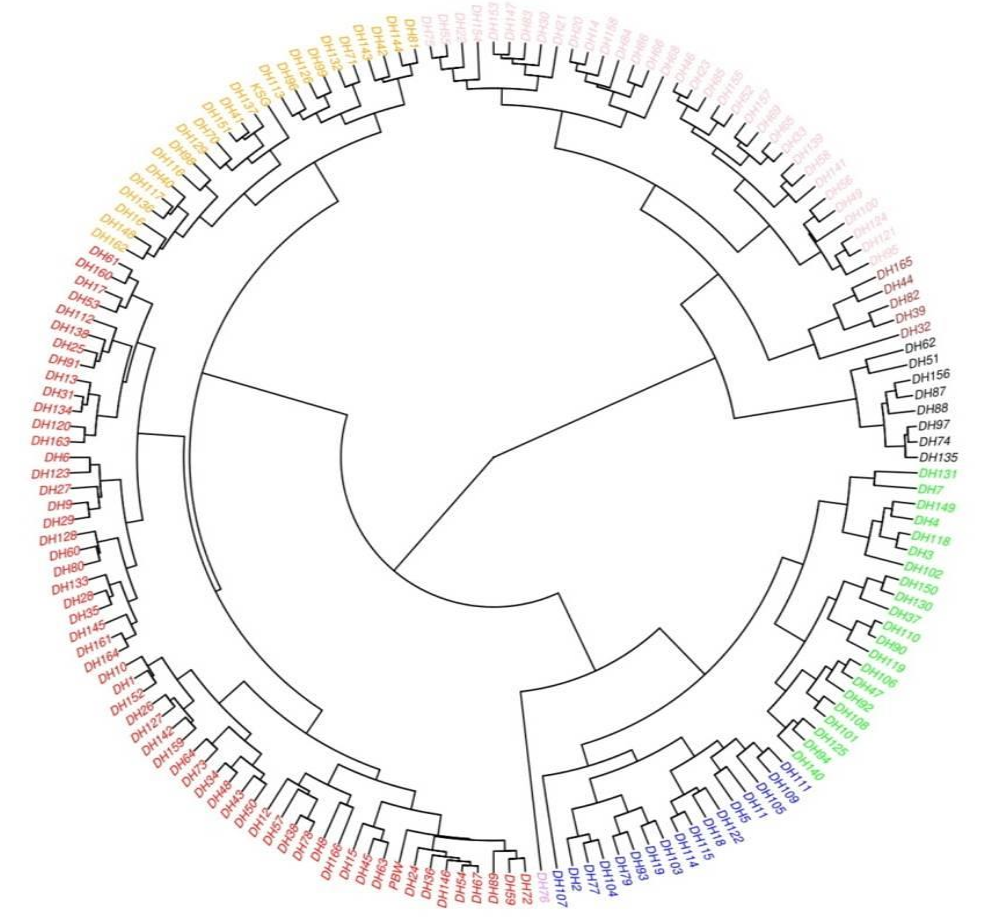

Fig 3: Dendrogram on the basis of phenotypic diversity present in doubled haploid lines 
bioRxiv preprint doi: https://doi.org/10.1101/2021.06.17.448834; this version posted June 17, 2021. The copyright holder for this preprint (which was not certified by peer review) is the author/funder, who has granted bioRxiv a license to display the preprint in perpetuity. It is made available under aCC-BY-NC-ND 4.0 International license.

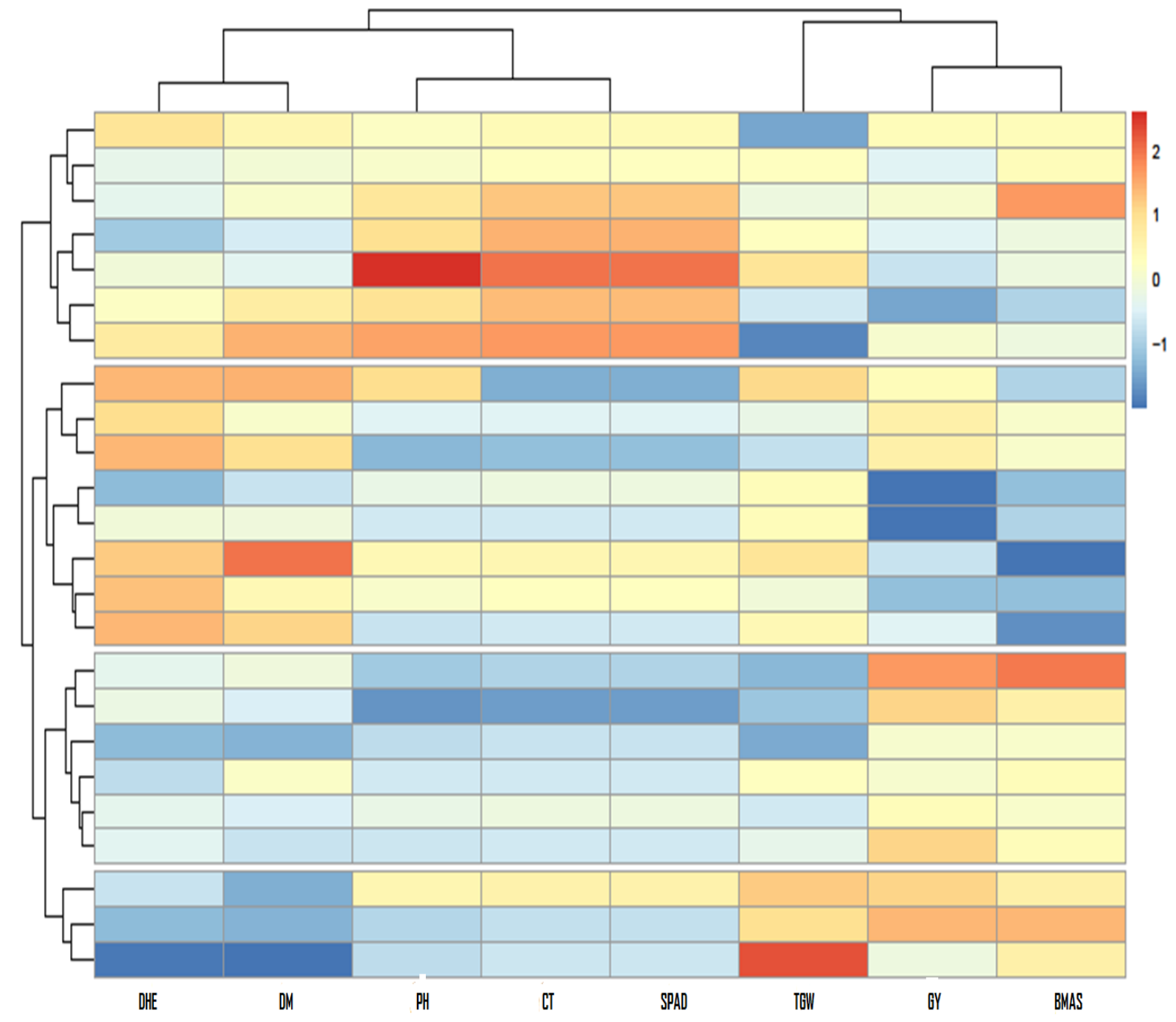

Fig 4: Heat maps illustrating the phenotypic correlation between all traits measured in the doubled haploid population PBW343/IC252874 
bioRxiv preprint doi: https://doi.org/10.1101/2021.06.17.448834 this version posted June 17, 2021. The copyright holder for this preprint

CII $3 B$

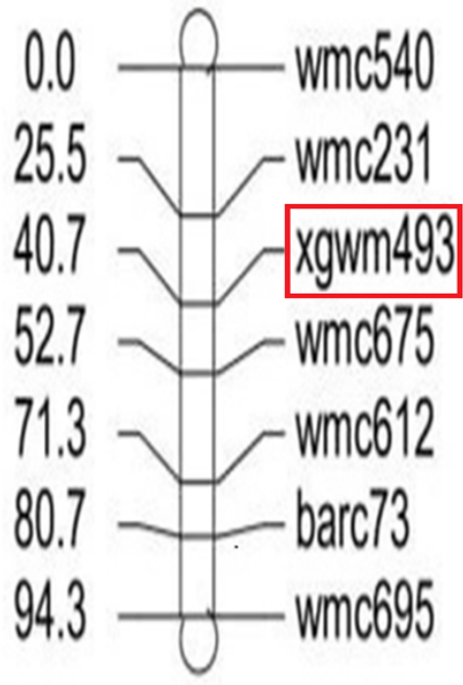

B

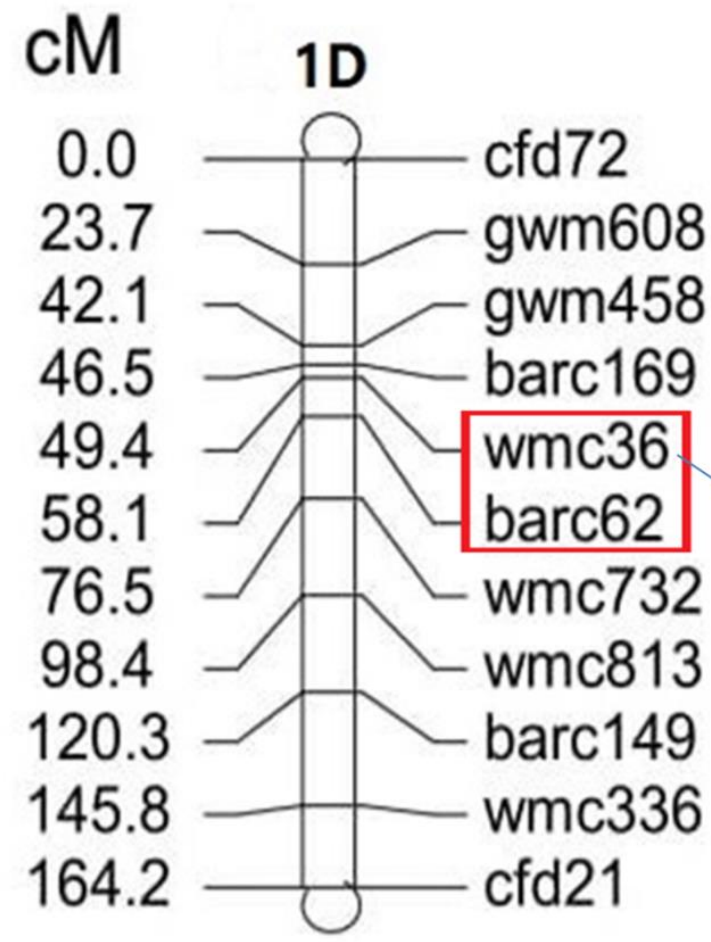

Chromosome3B $\quad \mathrm{Mb}$

(cM)

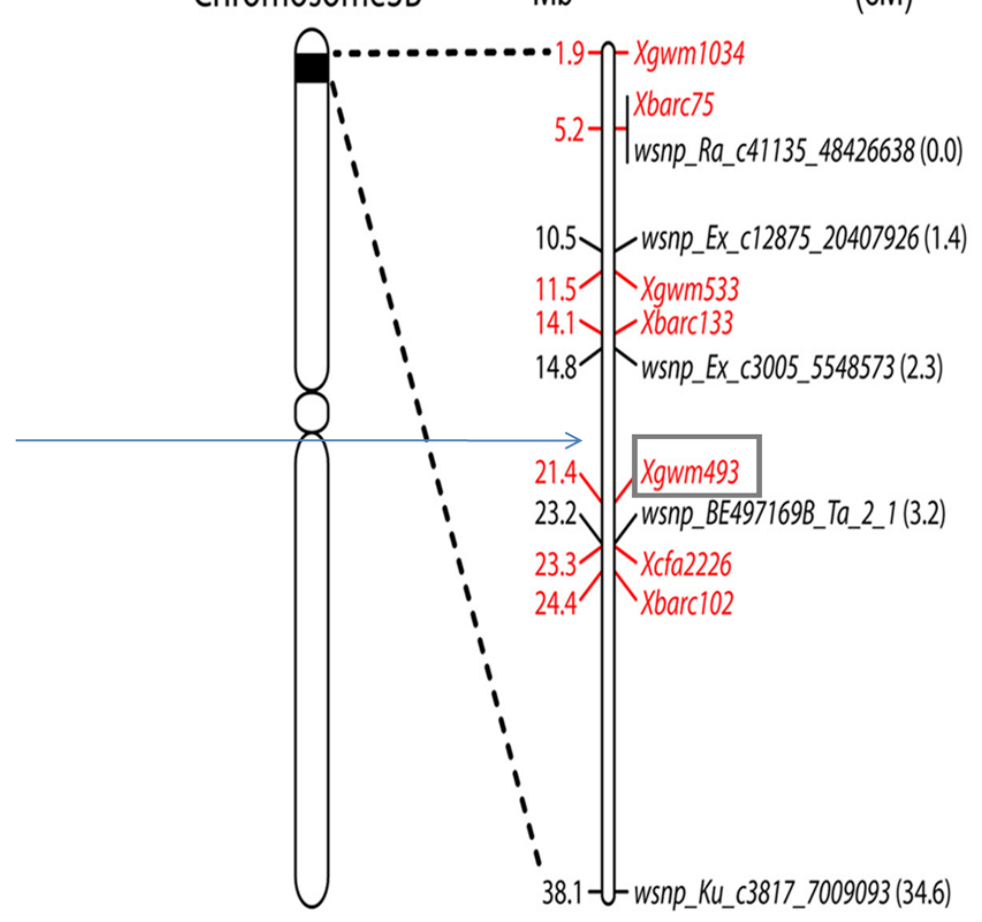

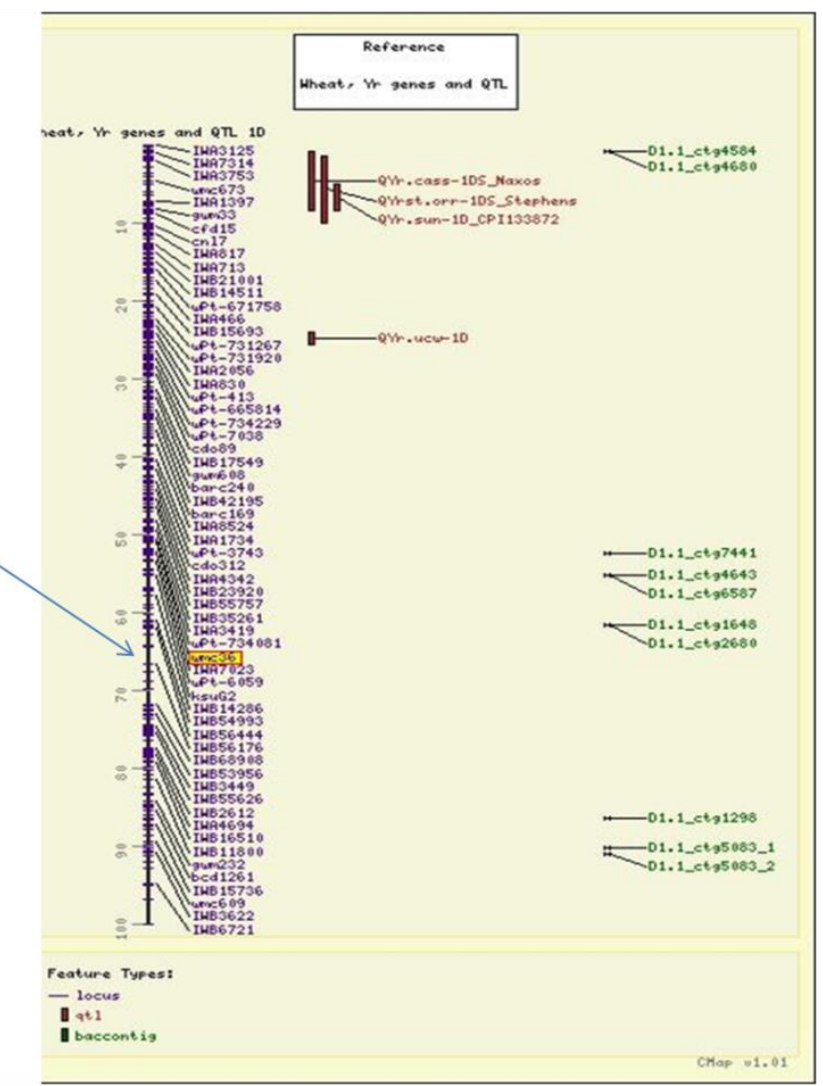


bioRxiv preprint doi: https://doi.org/10.1101/2021.06.17.448834 this version posted June 17 2021. The copyright holder for this preprint (which was not certified by peer review) is the author/funder, who has granted bioRxiv a license to display the preprint in perpetuity. It is made available under aCC-BY-NC-ND 4.0 International license.

C
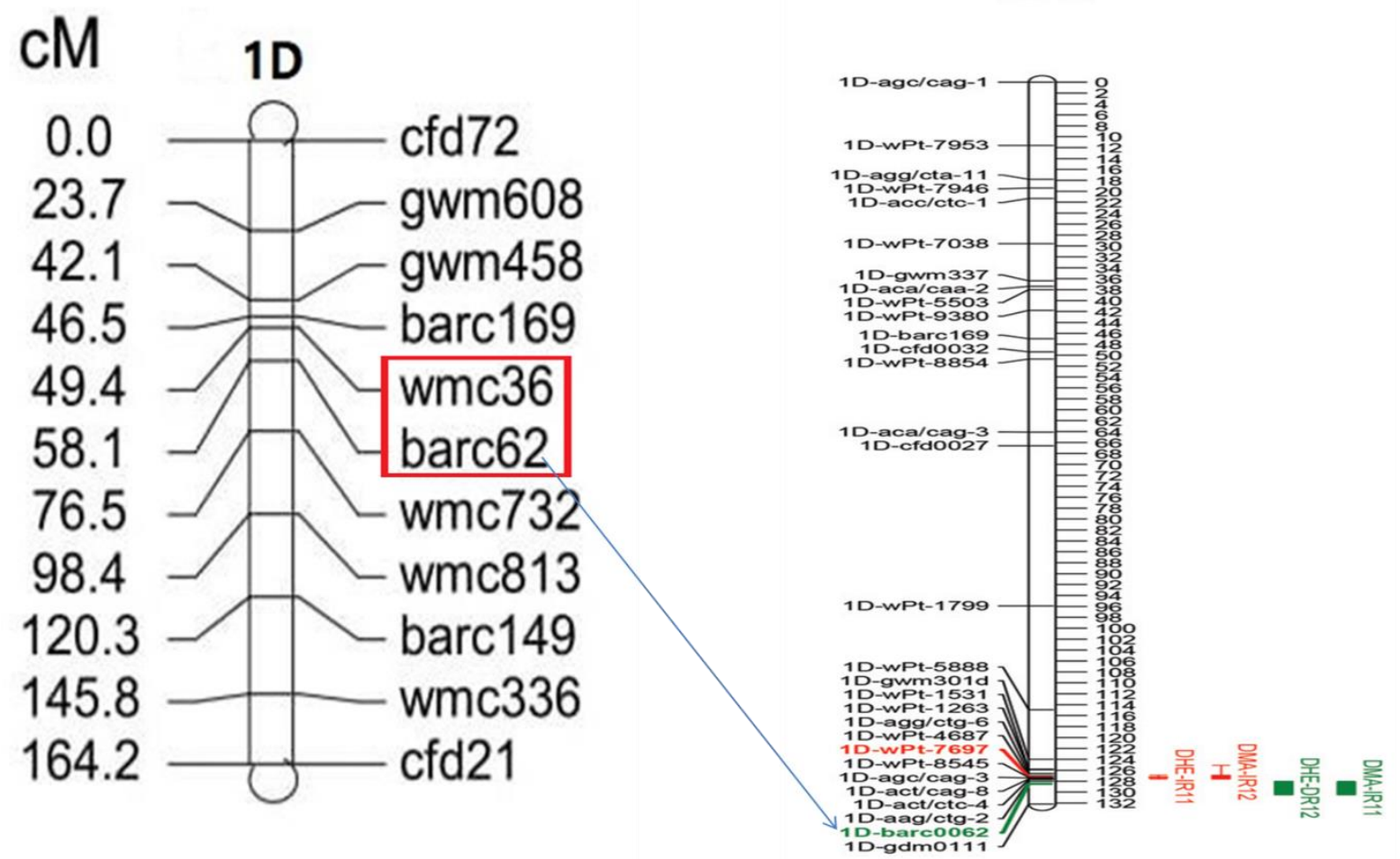

D

\section{Chromosome $1 \mathrm{~A}$}
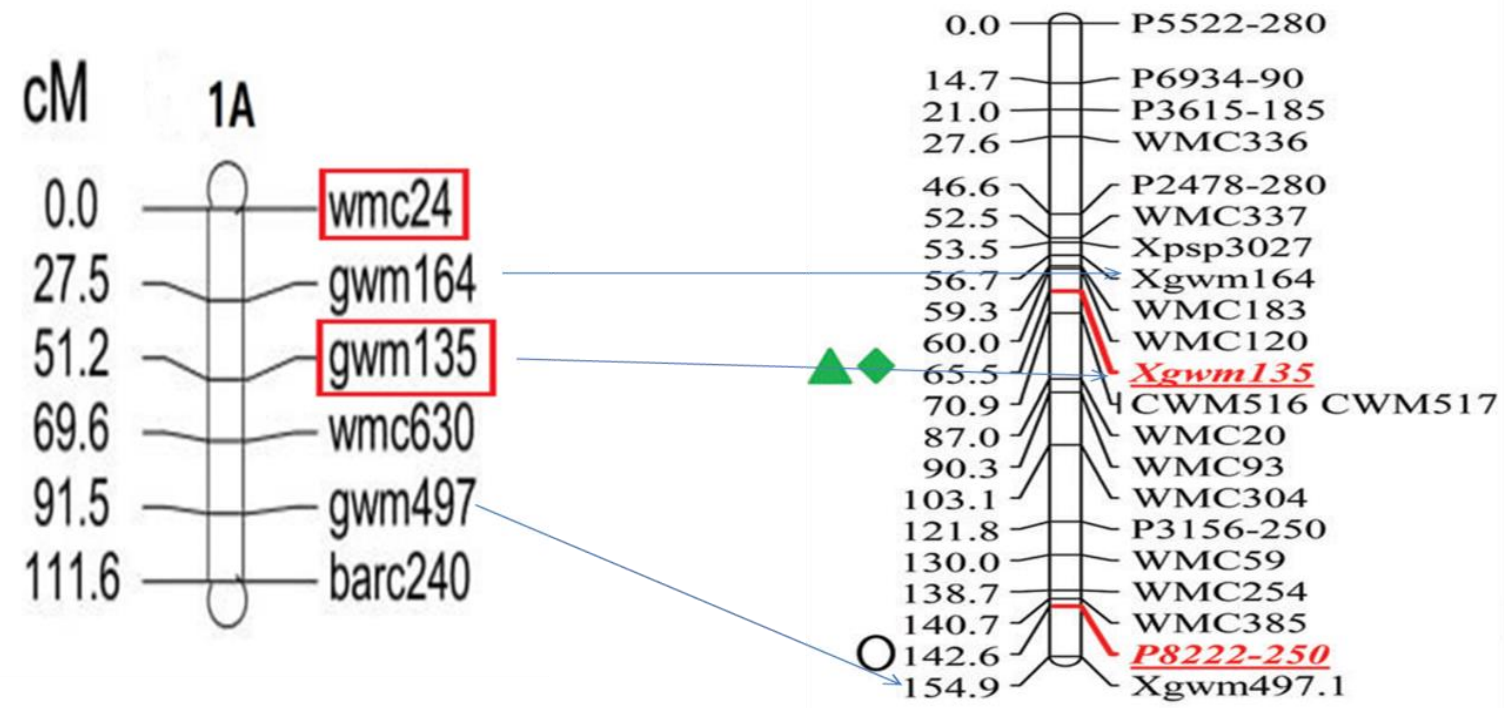
bioRxiv preprint doi: https://doi.org/10.1101/2021.06.17.448834 this version posted June 17 2021. The copyright holder for this preprint (which was not certified by peer review) is the author/funder, who has granted bioRxiv a license to display the preprint in perpetuity. It is made available under aCC-BY-NC-ND 4.0 International license.

$\mathbf{E}$

CM $1 \mathrm{~A}$

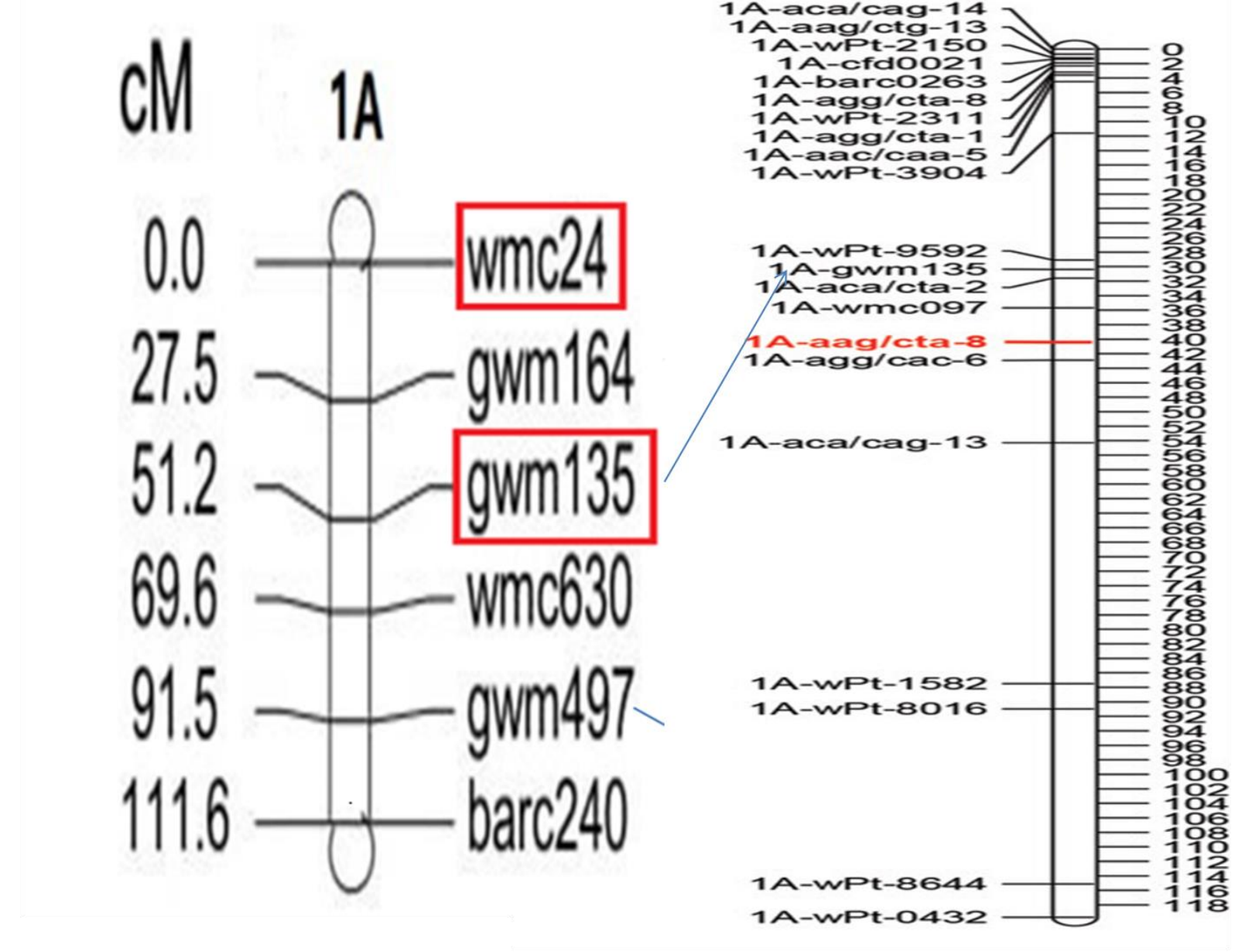


bioRxiv preprint doi: https://doi.org/10.1101/2021.06.17.448834 this version posted June 17, 2021. The copyright holder for this preprint (which was not certified by peer review) is the author/funder, who has granted bioRxiv a license to display the preprint in perpetuity. It is made available under aCC-BY-NC-ND 4.0 International license.

$\mathbf{F}$

CM $5 B$
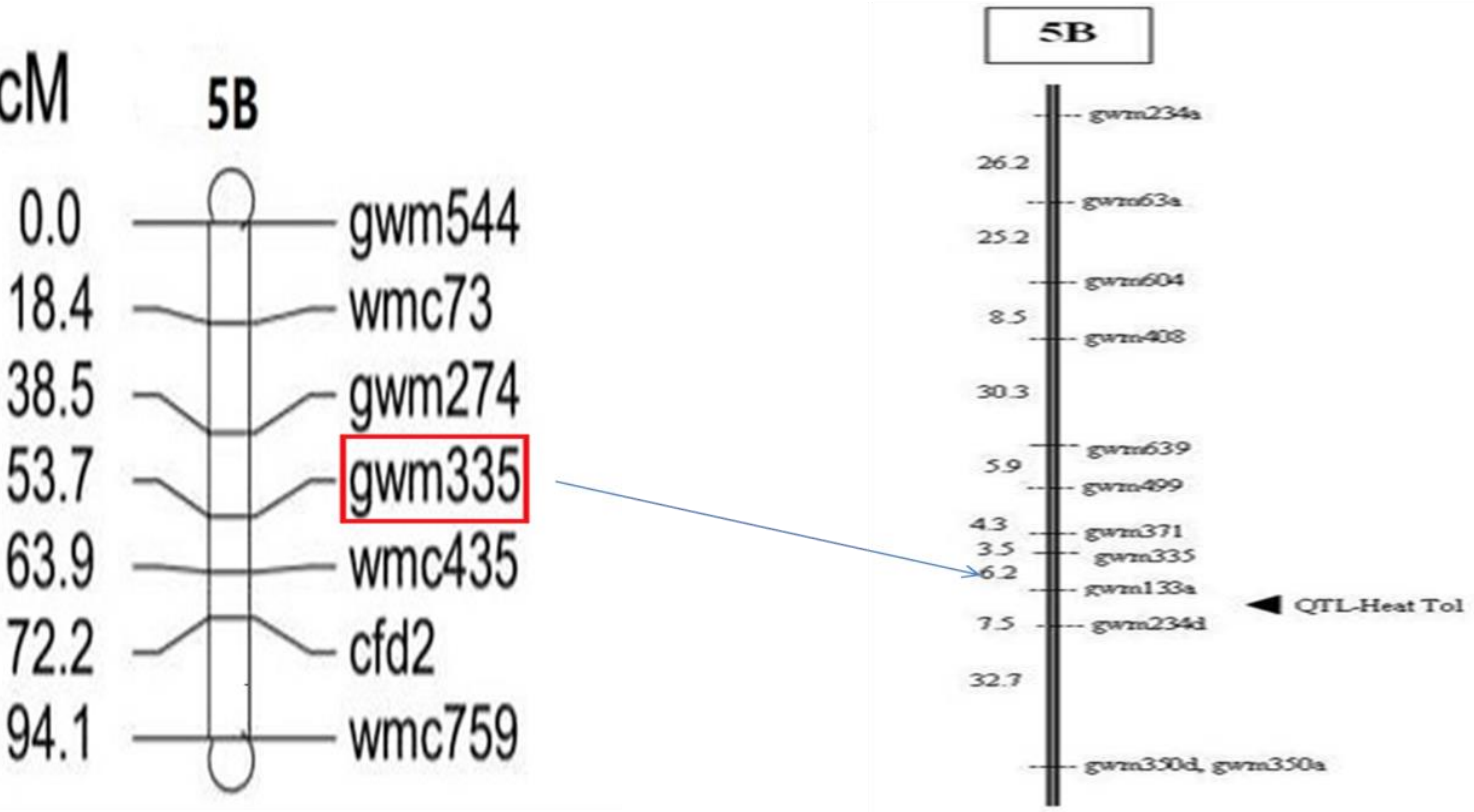

G

$\mathrm{CM} \quad 2 \mathrm{~B}$

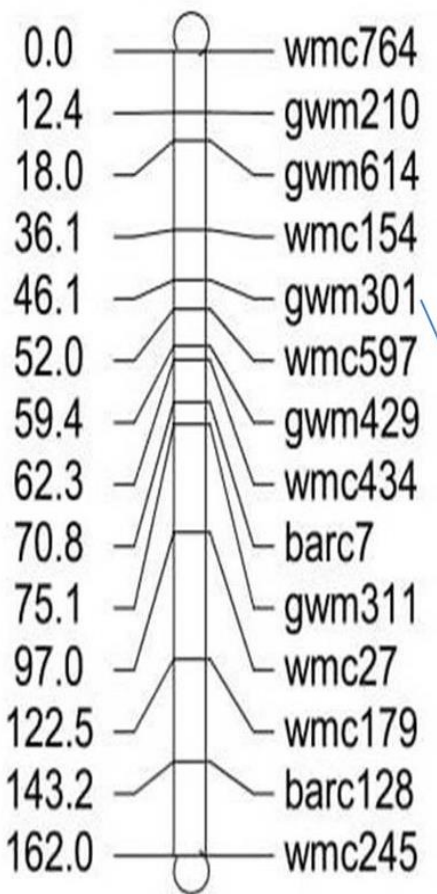

2B

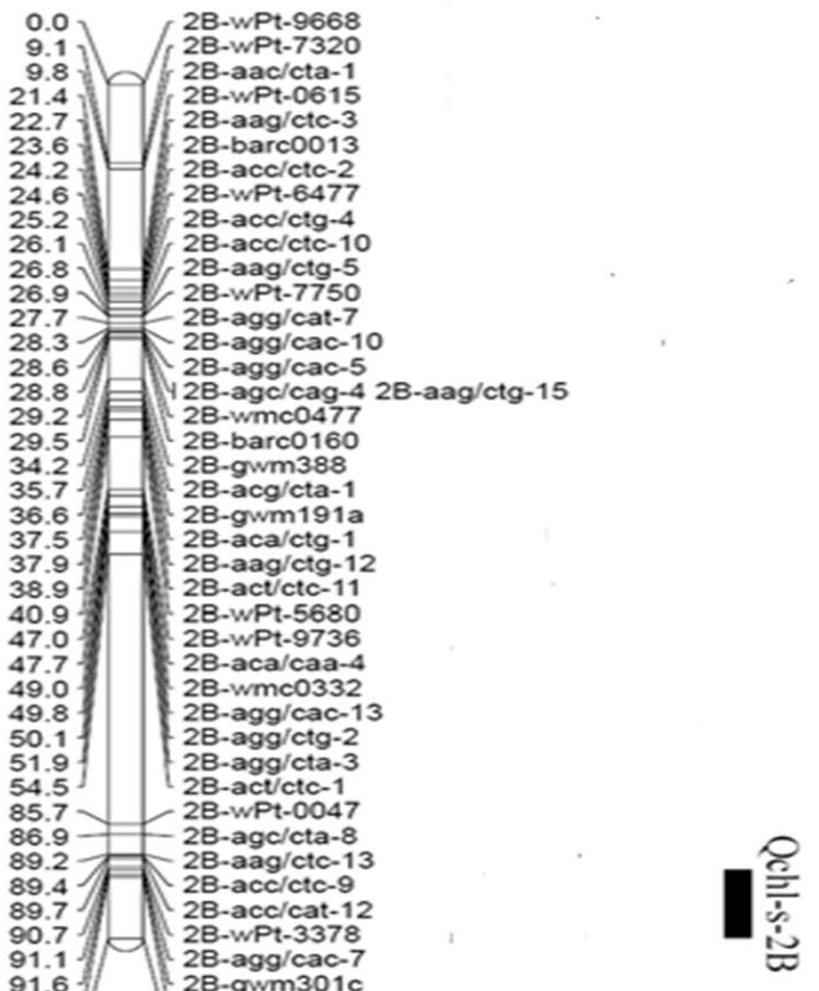




\section{D}
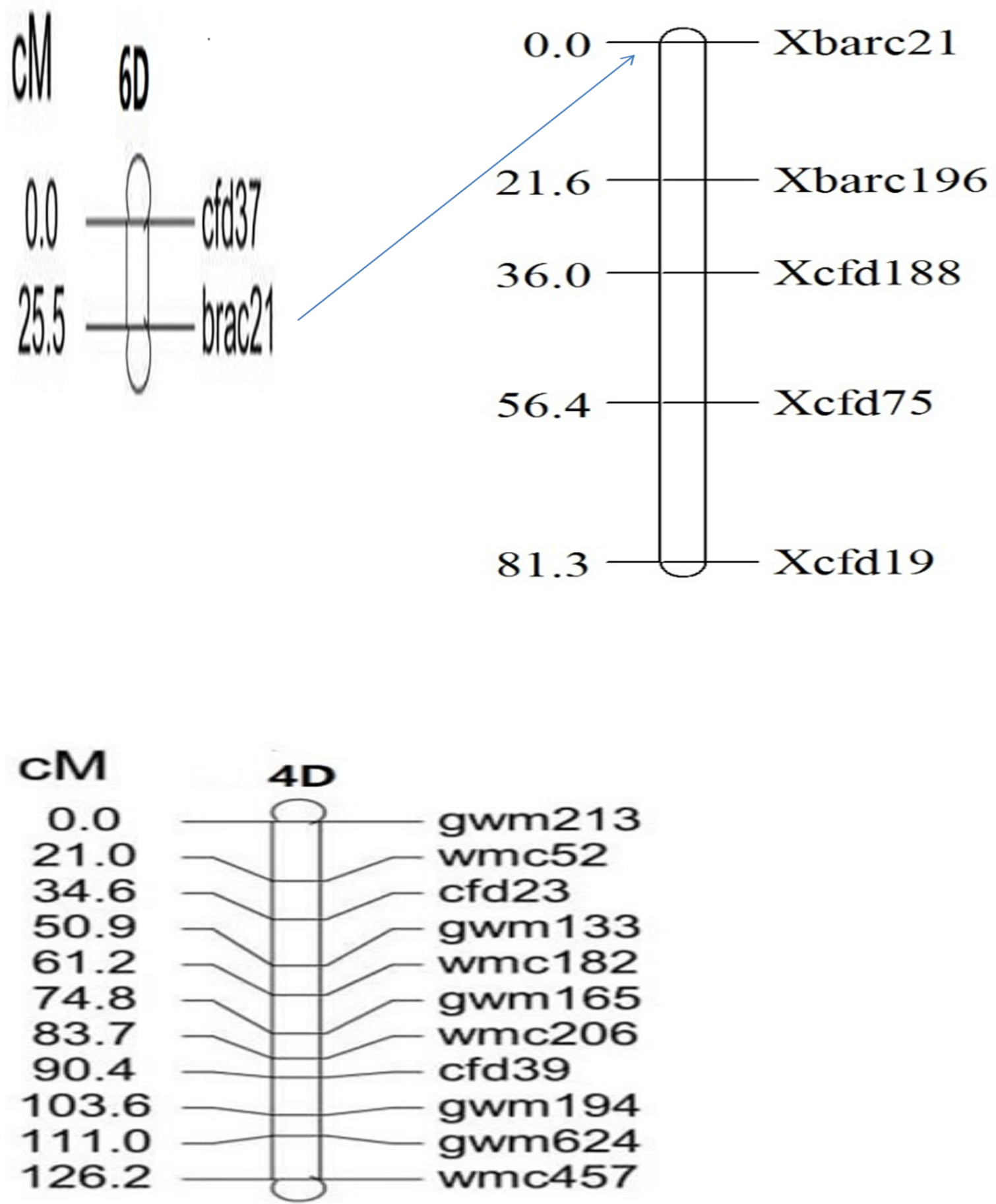

Fig 5: Genetic linkage map (A, B, C, D, E, F, G, H, I) of PBW343/IC252874 DH population with identified QTLs 
bioRxiv preprint doi: https://doi.org/10.1101/2021.06.17.448834; this version posted June 17, 2021. The copyright holder for this preprint (which was not certified by peer review) is the author/funder, who has granted bioRxiv a license to display the preprint in perpetuity. It is made available under aCC-BY-NC-ND 4.0 International license.
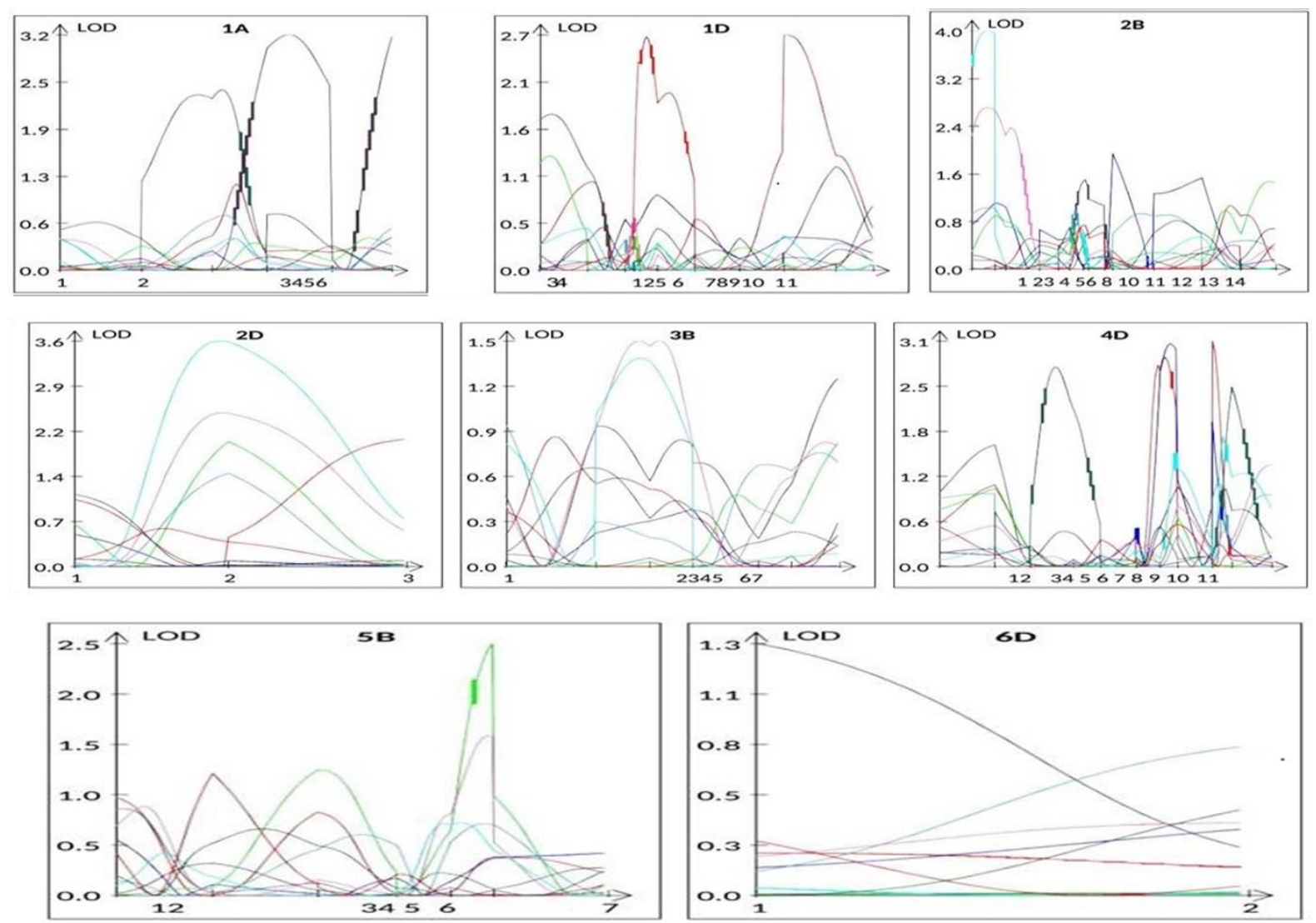

Fig 6: Representative QTL hits detected for various physiological and yield component traits in the PBW343/IC252874 DH population 


\begin{tabular}{|c|c|c|c|c|c|c|c|c|c|}
\hline Cluster & Parameters & DHE & DM & $\mathbf{P H}$ & TGW & GY & CT & SPAD & BMAS \\
\hline \multirow[t]{3}{*}{$\mathrm{I}$} & Mean & 71.322 & 109.47 & 98.46 & 36.45 & 145.61 & 35.09 & 42.11 & 466.2 \\
\hline & Max & 61 & 100 & 54.6 & 19.06 & 95 & 15.98 & 19.18 & 98 \\
\hline & Min & 79 & 116 & 137 & 81.2 & 223 & 61.99 & 74.39 & 674.5 \\
\hline \multirow[t]{3}{*}{ I I } & Mean & 68.6 & 111.2 & 100.94 & 37.8 & 141.2 & 33.49 & 40.19 & 295 \\
\hline & Max & 65 & 108 & 81.6 & 19.1 & 95 & 17 & 20.4 & 220 \\
\hline & Min & 70 & 113 & 116 & 80.1 & 221 & 59.99 & 71.99 & 500 \\
\hline \multirow[t]{3}{*}{ I I I } & Mean & 71.25 & 109 & 103.55 & 31.69 & 136.41 & 32.2 & 38.64 & 221.5 \\
\hline & Max & 66 & 101 & 57.8 & 19.98 & 97.3 & 15.98 & 19.18 & 101 \\
\hline & Min & 76 & 113 & 131 & 41.02 & 169 & 45.01 & 54.01 & 525 \\
\hline \multirow[t]{3}{*}{ IV } & Mean & 73 & 111 & 94 & 77.02 & 205 & 57.1 & 68.52 & 441.1 \\
\hline & Max & 69 & 120 & 90.01 & 82.03 & 201 & 63.2 & 75.3 & 340 \\
\hline & Min & 78 & 128 & 100.2 & 100.23 & 194.5 & 56 & 62 & 234 \\
\hline \multirow[t]{3}{*}{$\mathrm{V}$} & Mean & 72.375 & 109.46 & 104 & 31.26 & 134.67 & 32.39 & 38.87 & 505 \\
\hline & Max & 63 & 104 & 65 & 19.23 & 94.8 & 15.7 & 18.84 & 101 \\
\hline & Min & 81 & 116 & 142 & 45.09 & 183.3 & 55.18 & 66.22 & 735 \\
\hline \multirow[t]{3}{*}{ VI } & Mean & 71.059 & 109.59 & 95.74 & 31.98 & 137.35 & 32.3 & 38.76 & 403.2 \\
\hline & Max & 65 & 102 & 58 & 20.02 & 95 & 17.2 & 20.64 & 250 \\
\hline & Min & 77 & 115 & 131 & 42.09 & 177 & 50.09 & 60.11 & 685 \\
\hline \multirow[t]{3}{*}{ VI I } & Mean & 60 & 100.01 & 80.2 & 28.65 & 89.05 & 23.45 & 30 & 421.95 \\
\hline & Max & 71.29 & 108.53 & 92.79 & 35.88 & 145.54 & 36.05 & 43.26 & 645.2 \\
\hline & Min & 64 & 101 & 63.5 & 20.12 & 97 & 16.34 & 19.61 & 500 \\
\hline \multirow[t]{3}{*}{ VI I I } & Mean & 60.54 & 100 & 95 & 30 & 85 & 23.64 & 32.21 & 300.53 \\
\hline & $\operatorname{Max}$ & 70.857 & 108.38 & 102.41 & 38.51 & 153.82 & 37.5 & 45 & 531.3 \\
\hline & Min & 66 & 104 & 75 & 20.98 & 98 & 18.22 & 21.86 & 280 \\
\hline
\end{tabular}


bioRxiv preprint doi: https://doi org/10.1101/2021.06.17.448834; this version posted June 17,2021 . The copyright holder for this preprint (which was not certified by peer review) is the author/funder, who has granted bioRxiv a license to display the preprint in perpetuity. It is made available under aCC-BY-NC-ND 4.0 International license.

\begin{tabular}{|l|l|l|l|l|l|l|l|}
\hline Year & Trial & $\begin{array}{l}\text { Peak } \\
\text { Temp } \\
(\mathrm{month}) \\
(\mathrm{oC})\end{array}$ & $\begin{array}{l}\text { Sowing } \\
\text { date }\end{array}$ & $\begin{array}{l}\text { Harvesting } \\
\text { date }\end{array}$ & $\begin{array}{l}\text { AvgMax/AvgMin } \\
(\mathrm{oC})\end{array}$ & $\begin{array}{l}\text { Rain } \\
(\mathrm{mm})\end{array}$ & $\begin{array}{l}\text { RH } \\
(\%)\end{array}$ \\
\hline $2017-18$ & Control & $31($ Apr $)$ & 22 Nov & 11 Apr & $25.2 / 11.2$ & 18 & 46.5 \\
\hline & $\begin{array}{l}\text { Late } \\
\text { sowing }\end{array}$ & $39($ May) & 21 Jan & 19 May & $33.3 / 15.3$ & 16 & 40.3 \\
\hline $2018-19$ & Control & $30($ Apr) & 22Nov & 11Apr & $23.2 / 12.1$ & 19 & 43.8 \\
\hline & $\begin{array}{l}\text { Late } \\
\text { sowing }\end{array}$ & $38($ May) & 21 Jan & 29May & $31.1 / 12.3$ & 20 & 37.9 \\
\hline
\end{tabular}

Table 2: Peak temperature, average maximum and average minimum temperature, rain, relative humidity and pan evaporation during the cropping seasons (2017-18 and 2018-19)

\begin{tabular}{|l|l|l|l|l|l|l|l|l|l|}
\hline $\begin{array}{l}\text { Source of } \\
\text { Variation }\end{array}$ & df & DHE & DM & PHE & TGW & GY & CT & SPAD & BMAS \\
\hline Replications & 3 & $36.04^{* *}$ & $40.5^{* *}$ & $0.0087^{* *}$ & 10.60 & 12483.77 & $2.64^{*}$ & $9.7^{* *}$ & $4120^{* *}$ \\
\hline Year & 2 & $8.6^{*}$ & $854.1^{* *}$ & $639.9^{* *}$ & $3553.56^{* *}$ & $1476872.00^{* *}$ & $3770.45^{* *}$ & $7047.3^{* *}$ & 428 \\
\hline Line & 166 & $72.6^{* *}$ & $40.5^{* *}$ & $0.0143^{*}$ & $33.59^{* *}$ & $293175.25^{* *}$ & $1.75^{* *}$ & $2.8^{* *}$ & 350 \\
\hline Year X Line & 322 & $24.1^{* *}$ & $19.0^{* *}$ & $76.8^{* *}$ & $23.10^{* *}$ & $278252.75^{* *}$ & $1.55^{* *}$ & 1.97 & $6513^{* *}$ \\
\hline Error & 762 & 14.27 & $33.09^{*}$ & 4.179 & 11.10 & $157771.44^{* *}$ & 0.73 & 0.84 & $110.98^{*}$ \\
\hline Heritability & & 0.67 & 0.53 & 0.50 & 0.67 & 0.72 & 0.70 & 0.68 & 0.50 \\
\hline
\end{tabular}

Table 3: Pooled Analysis of variance for different morpho-physiological and yield traits 
bioRxiv preprint doi: https://doi.org/10.1101/2021.06.17.448834; this version posted June 17,2021 . The copyright holder for this preprint (which was not certified by peer review) is the author/funder, who has granted bioRxiv a license to display the preprint in perpetuity. It is made available under aCC-BY-NC-ND 4.0 International license.

\begin{tabular}{|c|c|c|c|c|c|c|c|c|}
\hline \multirow[t]{2}{*}{ QTL/Trait } & \multirow[t]{2}{*}{ Marker Interval } & \multirow[t]{2}{*}{ Chrom } & \multicolumn{3}{|c|}{$2017-18$} & \multicolumn{3}{|c|}{ 2018-19 } \\
\hline & & & LOD & PVE\% & Additive & LOD & PVE\% & Additive \\
\hline E1(Normal & & & & & & & & \\
\hline$\overline{\mathrm{DM}}$ & cfd23-gwm133 & $4 \mathrm{D}$ & 3.02 & 6.72 & -1.23 & & & \\
\hline GY & Wmc231-Xgwm493 & 3B & 9.01 & 18.42 & 0.94 & 7.78 & 11.84 & -0.151 \\
\hline E2 (Delayec & & & & & & & & \\
\hline DHE & Wmc36-barc62(sirous), & 1D & 4.02 & 9.31 & -2.04 & 6.68 & 15.71 & 1.987 \\
\hline $\mathrm{DM}$ & Wmc36-barc62 & $1 \mathrm{D}$ & 3.78 & 6.24 & -1.46 & 5.61 & 12.36 & 0.985 \\
\hline GY & Wmc231-Xgwm493 & 3B & 8.52 & 21.24 & 1.84 & 8.74 & 13.45 & -0.128 \\
\hline GY & Wmc36-barc62 & $1 \mathrm{D}$ & 7.02 & 19.32 & 1.22 & 8.23 & 12.31 & -0.102 \\
\hline $\mathrm{CT}$ & Gwm164-Wmc24 & $1 \mathrm{~A}$ & 9.81 & 6.78 & -0.136 & 11.21 & 18.34 & -0.159 \\
\hline SPAD & Xgwm135-Gwm164 & $1 \mathrm{~A}$ & 18.73 & 8.31 & -0.127 & 21.35 & 12.20 & -1.045 \\
\hline$\overline{G Y}$ & gwm335-gwm274 & 5B & 14.43 & 4.51 & -0.185 & 17.83 & 25.61 & 0.431 \\
\hline SPAD & Gwm301-wmc597 & 2B & 6.71 & 10.48 & -0.103 & 4.35 & 13.43 & -1.39 \\
\hline TGW & Barc21-cfd37 & $6 \mathrm{D}$ & 6.43 & 10.03 & -0.834 & 8.45 & 8.49 & -0.102 \\
\hline SPAD & Xgwm135-Gwm164 & $1 \mathrm{~A}$ & 5.23 & 13.1 & 5.61 & 7.42 & 25.31 & 0.261 \\
\hline$\overline{\mathrm{DM}}$ & Gwm164-Wmc24 & $1 \mathrm{~A}$ & 4.25 & 9.24 & -0.165 & 5.65 & 11.28 & 0.110 \\
\hline
\end{tabular}

Table 4: NS (Normal sown) and LS ( late sown), Position LOD, A LOD threshold of 2.5 was used for declaration of QTL, PVE (\%), Phenotypic variance explained by QTL, Additive effect, Positive "additive effect "indicates an increasing effect from PBW343; negative "additive effect" indicates an increasing effect from IC252874 
bioRxiv preprint doi: https://doi.org/10.1101/2021.06.17.448834; this version posted June 17, 2021. The copyright holder for this preprint (which was not certified by peer review) is the author/funder, who has granted bioRxiv a license to display the preprint in perpetuity. It is made available under aCC-BY-NC-ND 4.0 International license. 
bioRxiv preprint doi: https://doi.org/10.1101/2021.06.17.448834; this version posted June 17, 2021. The copyright holder for this preprint (which was not certified by peer review) is the author/funder, who has granted bioRxiv a license to display the preprint in perpetuity. It is made available under aCC-BY-NC-ND 4.0 International license. 